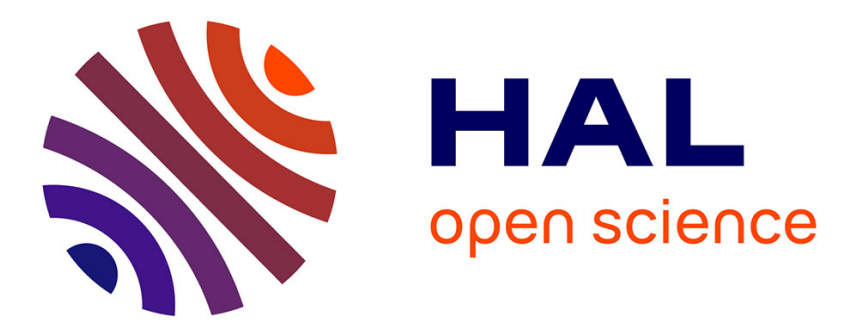

\title{
First Records of Lohmanniidae (Acari, Oribatida) from the Bermuda Islands
}

\author{
H. Schatz, Romain Schuster
}

\section{To cite this version:}

H. Schatz, Romain Schuster. First Records of Lohmanniidae (Acari, Oribatida) from the Bermuda Islands. Acarologia, 2012, 52 (3), pp.244-257. 10.1051/acarologia/20122064 . hal-01567091

\section{HAL Id: hal-01567091 \\ https://hal.science/hal-01567091}

Submitted on 21 Jul 2017

HAL is a multi-disciplinary open access archive for the deposit and dissemination of scientific research documents, whether they are published or not. The documents may come from teaching and research institutions in France or abroad, or from public or private research centers.
L'archive ouverte pluridisciplinaire HAL, est destinée au dépôt et à la diffusion de documents scientifiques de niveau recherche, publiés ou non, émanant des établissements d'enseignement et de recherche français ou étrangers, des laboratoires publics ou privés.

\section{(ㅇ)(1) $\$$}

Distributed under a Creative Commons Attribution - NonCommercial - NoDerivatives| 4.0 


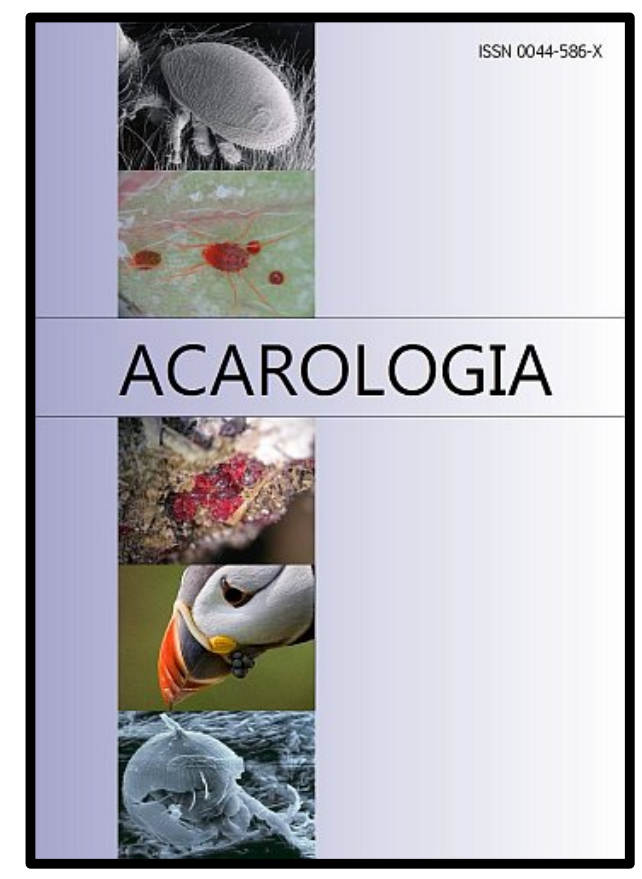

\section{ACAROLOGIA}

A quarterly journal of acarology, since 1959

Publishing on all aspects of the Acari

All information:

http://www1.montpellier.inra.fr/CBGP/acarologia/ acarologia@supagro.inra.fr

\section{OPEN ACCESS}

\section{Acarologia is proudly non-profit, with no page charges and free open access}

Please help us maintain this system by encouraging your institutes to subscribe to the print version of the journal and by sending us your high quality research on the Acari.

Subscriptions: Year 2017 (Volume 57): $380 €$ http://www1.montpellier.inra.fr/CBGP/acarologia/subscribe.php

Previous volumes (2010-2015): $250 € /$ year (4 issues)

Acarologia, CBGP, CS 30016, 34988 MONTFERRIER-sur-LEZ Cedex, France

The digitalization of Acarologia papers prior to 2000 was supported by Agropolis Fondation under the reference ID 1500-024 through the « Investissements d'avenir » programme

(Labex Agro: ANR-10-LABX-0001-01)
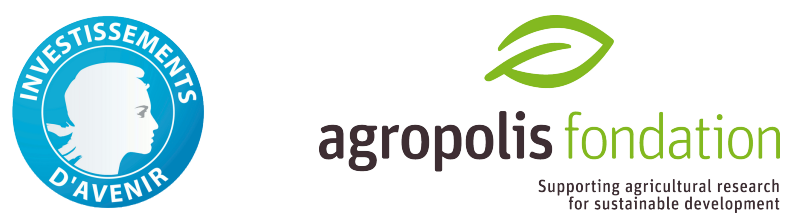

Acarologia is under free license and distributed under the terms of the

Creative Commons-BY-NC-ND which permits unrestricted non-commercial use, distribution, and reproduction in any medium, provided the original author and source are credited. 


\title{
FIRST RECORDS OF LOHMANNIIDAE (ACARI: ORIBATIDA) FROM THE BERMUDA ISLANDS
}

\author{
Heinrich SCHATZ ${ }^{1}$ and Reinhart SCHUSTER ${ }^{2}$
}

(Received 12 June 2012; accepted 27 June 2012; published online 27 September 2012)

\footnotetext{
${ }^{1}$ Institute of Zoology, University of Innsbruck, Technikerstr. 25, A-6020 Innsbruck, Austria. Heinrich.Schatz@uibk.ac.at 2 Institute of Zoology, Karl-Franzens University Graz, Universitaetsplatz 2, 8010 Graz, Austria. reinhart.schuster@uni-graz.at
}

\begin{abstract}
Records of nine species of the family Lohmanniidae from the Bermuda Islands, belonging to six genera, are presented and discussed (Haplacarus foliatus Wallwork, 1962, Lohmannia banksi Norton, Metz et Sharma, 1978, L. jornoti Mahunka, 1985, L. similis Balogh, 1962, Meristacarus porcula Grandjean, 1934, Nesiacarus granulatus Hammer, 1972, Papillacarus incompletus (Mahunka, 1985), P. spinosus Bischoff de Alzuet, 1972, Torpacarus omittens omittens Grandjean, 1950). Morphological characteristics, ecology and zoogeographical relationships are analysed. Most Lohmanniidae species were found in terrestrial habitats, a few species colonize the salt-spray area of the supralittoral zone or even the upper eulittoral zone, mainly in mangrove leaf litter. Almost all Lohmanniidae species found on Bermuda occur also in Central or South America. Dispersal by hydrochory can be assumed for most species.
\end{abstract}

KEYWORDS - Acari; Oribatida; Lohmanniidae; Bermuda; ecology; zoogeography

\section{INTRODUCTION}

The knowledge of the oribatid mite fauna from the Bermuda Islands is still very poor. Prior to this study 23 species have been recorded. Sellnick (1952) published the first three species collected on Bermuda. Oripoda longiseta Woolley, 1966 was discovered in the slide series from the U.S. National Museum, which was originally found on plant material ("unknown cuttings") at Boston, introduced from Bermuda without detailed site records (Woolley 1966, Balogh and Balogh 1990). Niedbala (2002) recorded 18 "Ptyctimous" oribatid species from Bermuda. Among them, three species (Atropacarus paraclavatus Niedbala, 2002, Mesoplophora paragaveae Niedbala, 2002, Phauloppia gracilis Sellnick, 1952) were found exclusively on Bermuda up to now. Recently a new species of the family Fortuyniidae, Fortuynia atlantica Krisper et Schuster, 2008 was described which is hitherto only known from the Bermuda Islands, occurring in many localities along the rocky coastlines (Krisper and Schuster 2008). An additional study, also about littoral oribatid mites, was published by Pfingstl and Schuster (2012). In the course of two collecting trips made by the second author to the Bermudas in the summers of 1977 and 1981, numerous Lohmanniidae species were collected. These taxa are presented in the present paper.

\section{ENVIRONMENTAL SETTING}

The Bermuda Archipelago, located near the western edge of the Sargasso Sea in the Atlantic Ocean, 
consists of about 150 islands with a total terrestrial surface of $55 \mathrm{~km}^{2}$, the largest island of which, called "Main island" or "Bermuda" covers about $40 \mathrm{~km}^{2}$. Most of the other islands are very small and devoid of dense terrestrial vegetation. The islands are of oceanic origin, a land bridge to the American continent has never existed. The nearest distance to Cape Hatteras, North America, is about $960 \mathrm{~km}$. Originally formed by a volcanic seamount the subaereal part is covered by coralline limestone, partially broken down into sand and fused to aeolian sandstone. The islands are largely flat, the highest point is Town Hill on Main island with an altitude of less than $100 \mathrm{~m}$. There is no mountainous region. On the other hand, the islands have more than $100 \mathrm{~km}$ of coastline, surrounded by coral reefs. Ecologically the shoreline can be divided into three different parts: sandy beaches, rocks, and remains of a typical mangrove vegetation on some coastal sections. The inland environment is poor and characterized by sandy soils with low amounts of organic matter, small forests, bushes and grassland. Rivers or brooks are absent. Remarkable are numerous Karst caves.

The climate of the Bermudas is subtropical. It is largely influenced by the Gulf Stream which represents an important climatic factor. Additionally, this ocean current arising in the Caribbean region, is a significant factor for the colonization of the Bermuda islands by plants and animals.

The terrestrial vegetation includes different trees and shrubs, forming forests in some places. Endemic plants are rare (e.g. Juniperus bermudiana, "Bermuda Cedar" or Sabal bermudana, "Bermuda Palmetto", the only native palm). Since discovery by humans in 1503, numerous species have been introduced to the islands, deliberately or accidentally, which were responsible for the remarkable changes in the native flora and fauna of the archipelago as well as the subsequent changes in the original vegetation and landscape. A characteristic introduction is the Australian Casuarina-tree.

Details about the natural history of the Bermudas are given in Thomas (2004).

\section{MATERIAL AND METHODS}

List of Localities:

BE-26: Campus of the Biological Station; fully terrestrial location, sandy soil with some litter under a group of bushes; 20.7.1977

BE-30: Forest near Tom Moore's Tavern; in the neighbourhood of a small salty pool; muddy soil; 31.7.1977

BE-59: Burt Island in the Great Sound; flat supralittoral; sandy soil with a lot of gravel; 7.8.1977

BE-117: Forest near Tom Moore's Tavern; bushes near Walshingham cave; moist soil with litter, on the edge of a salty pool; 19.7.1981

BE-119: Neighborhood of Tom Moore's Tavern, at the edge of the Harbour's Pool; forest of brushes; moist soil with litter, at the rim of a small brackish pool; 19.7.1981

BE-124: Campus of the Biological Station; dry sandy soil with litter under Casuarina-trees; 20.7.1981

BE-126: Campus of the Biological Station; similar to BE-124, but at a distance of $12 \mathrm{~m}$; 20.7.1981

BE-184: Small island W of Trunk Island in the Harrington Sound; thin soil layer with some litter; 10.8.1981

BE-225: Somerset Island, near Scaur Fort; open area; poor soil, mixed with sand; 29.8.1981

BE-230: St. George's, Lovers Lake, upper edge of the mangroves; sandy-muddy soil with threads of green algae on the surface; 31.8.1981

BE-282: Somerset Island, Mangrove Bay; transition zone between supralittoral and terrestrial area; moist sandy soil; 14.9.1981

BE-285: West shore, ca. $200 \mathrm{~m}$ S of Whitney Bay; sandy beach, just above the supralittoral; terrestrial sandy slope; 17.9.1981

BE-287: Parish Southampton, hill of Gibbs Lighthouse; forest on the northern slope; dry sand covered with a layer of dry litter; 20.9.1981

BE-288: Parish Warwick; forest east of the Warwick pond; dry coarse-grained soil, with dry litter on the surface; 21.9.1981 
BE-299: Coast of Penthurst Park; beach, coarsegrained soil in the transition between supralittoral and terrestrial zone; 24.9.1981

BE 301: Devonshire Bay (part Rocky Bay); little sandy beach between rocks; soil below jetsam in the transition zone between supralittoral and terrestrial area; 24.9.1981

BE-303: Parish Smith's, southcoast, John Smith's Bay; upper part of the beach, transition zone up to the terrestrial area; 25.9.1981

BE-308: Walsingham Nature Reserve; forest near a small pool; moist soil, covered by a thin layer of litter; 26.9.1981

BE-310: Spittal Pond Nature Reserve; mixed forest with different trees and shrubs; reddish-grey soil with litter, mixed with sand; 26.9.1981

The mites were collected by using BerleseTullgren-funnels at the Biological Station of the Bermudas. All collections were carried out by the second author. The lohmanniid specimens investigated in this work are deposited in the collection of the first author. A total of 127 specimens were encountered, 55 adults and 72 juvenile instars.

\section{RESULTS}

\section{Haplacarus foliatus Wallwork, 1962}

Wallwork 1962: 466, figs. 6-11; Balogh and Balogh 1987: 343, pl. 29A; 2002a: 71; 2002b: pl. 126:1.

Dimensions: deutonymph $(\mathrm{n}=3) 518(480-540) \mathrm{x}$ $280 \mu \mathrm{m}$, tritonymph $(\mathrm{n}=2) 660 \times 290-330 \mu \mathrm{m}$. Sensillus with 7-8 branches in both instars. Measurements of setae: deutonymph: $c 165-70, d 160-70$, e1 70, f1 59 - 60, distance $c 1-d 170-80$, d1-e1 70; tritonymph: $c 180-85, d 180$, e1 $80-85$, f1 $60-70$, distance $c 1-d 1$ 90, e1-f1 $85-90 \mu \mathrm{m}$. Transverse band $s 7$ incomplete in all studied specimens.

Remarks: The specimens from Bermuda correspond to the original description (Wallwork 1962) and are considered conspecific. The description by Wallwork (1962) is based on one adult and one tritonymph. Haplacarus foliatus is very similar to H. javensis Hammer, 1979. Main differences between the two species are: The notogastral setae are thicker in adults of $H$. foliatus, but more slender in $H$. javensis (this character could not be observed in the studied juvenile instars); notogastral setae $e 1$ are longer than $f 1$ in $H$. foliatus; transverse band $s 7$ is incomplete in $H$. foliatus, but complete in $H$. javensis. A comparison with adults and tritonymphs of $H$. javensis from Belize and Cocos Island, Costa Rica (Schatz 1994b), was possible. Haplacarus foliatus is also morphologically similar to $H$. bengalensis Bhattacharya, Bhaduri et Raychaudhuri, 1974, but the latter species has shorter notogastral setae.

Records from Bermuda: BE 230: 2 deutonymphs. BE 301: 1 deutonymph, 2 tritonymphs.

General distribution: West Africa: Ghana, Pagalu Island (Annobón); India, Philippines, Thailand; first record for Bermuda.

\section{Lohmannia banksi Norton, Metz et Sharma, 1978}

Norton et al. 1978: 18, figs. 2-3; Balogh and Balogh 1987: 334, pl. 7 A-B.

Dimensions: adult $(\mathrm{n}=13) 846(770-915) \times 388$ (365 - 405), larva $(\mathrm{n}=7) 413(375-435) \times 211(190-$ 225), protonymph $(n=14) 511(460-565) \times 264(250$ - 280), deutonymph $(\mathrm{n}=4) 615(600-640) \times 312(300$ - 320), tritonymph $(\mathrm{n}=5) 744(685-820) \times 372(340-$ 400) $\mu \mathrm{m}$.

Prodorsum very weakly three-lobed. Sensillus with 10-12 branches in adult, trito- and deutonymph, 10 branches in protonymph, 8-9 branches in larva. Posterior exobothridial setae except in larva almost circular, measurements $50-60 \times 40-$ 55 in adult, $48-50 \times 40-48$ in tritonymph, $35-38 \times$ $32-35$ in deutonymph, $25 \times 20-25$ in protonymph, $20 \times 7 \mu \mathrm{m}$ in larva. Notogastral setae phylliform with serrated margins and with an obtuse, blunt tip, but at least distally with a weakly developed midrib in adult. Juvenile instars generally with smaller setae, dorsomedian setae in larva very weakly dilated with serrated margins, other notogastral setae gradually dilated to phylliform with a midrib in other instars. Posterior medial genital setae slightly widened in adult.

Remarks: A comparison with the paratype of this species was possible. The adult and juvenile specimens found on Bermuda correspond to this 
type (adult) and the original description (Norton et al. 1978) and are considered conspecific. Leaf-like notogastral setae of different shape are found in several species of the genus. In their key of the genus Lohmannia, Balogh and Balogh (1987) state the notogastral setae of this species "without midrib" but apparently they misinterpreted the drawing of Norton et al. (1978), where the midribs of the notogastral setae are barely indicated and not specially mentioned in the text. The body size of all instars from the population in Bermuda are in the range of the population from North Carolina.

Records from Bermuda: BE 26: 2 larvae. BE 30: 2 adults, 1 tritonymph, 1 deutonymph, 2 protonymphs, 2 larvae. BE 119: 2 adults, 2 tritonymphs, 2 deutonymphs, 4 protonymphs, 1 larva. BE 124: 1 adult, 1 tritonymph, 1 protonymph, 1 larva. BE 126: 5 adults, 1 protonymph, 2 larvae. BE 282: 2 adults, 2 protonymphs. BE 285: 1 tritonymph, 1 deutonymph. BE 287: 1 adult, 2 protonymphs. BE 288: 2 protonymphs. BE 303: 1 adult. BE 310: 1 adult.

General distribution: USA, North Carolina: pine-forest floor in Durham County (Norton et al. 1978) Texas (McDaniel et al. 1979); Mexico, Quintana Roo: Sian Ka'an, lowland inundation forest, in leaf litter and soil (Vazquez 1999); first record for Bermuda.

\section{Lohmannia jornoti Mahunka, 1985}

Mahunka 1985a: 124, f. 11-15; Balogh and Balogh 1987: 334, pl. 8 A; 1988: 53, pl. 33 F; 2002a: 65; 2002b: pl. 116:12; Schatz 1993: 70, figs. 1-6.

Dimensions: adult $800-840 \times 380-460 \mu \mathrm{m}$, deutonymph $540 \times 335 \mu \mathrm{m}$.

Sensillus with 12 branches in adult, 10 branches in deutonymph, posterior exobothridial setae wide, size $45 \times 30 \mu \mathrm{m}$ in adult, $35 \times 15 \mu \mathrm{m}$ in deutonymph. Medial notogastral setae phylliform with serrated margins, narrow. Posterior medial genital setae setiform and ciliate.

Remarks: A direct comparison with specimens from Galapagos was possible. The specimens from Bermuda correspond to those and the original description (Mahunka 1985a) in most respects and are considered conspecific. The body size of the specimens from Bermuda is in the range of the population from Guadeloupe (length $794-826 \mu \mathrm{m}$ ) but considerably smaller than the population from the Galapagos Islands (930 - $1020 \mu \mathrm{m}$, Schatz 1993). Also the deutonymph is smaller than in specimens from Galapagos $(680$ - 725 x $355-380 \mu \mathrm{m}$, Schatz 1993). The species is very similar to L. banksi Norton et al., 1978. It differs mainly in having smaller posterior exobothridial setae, smaller and differently shaped notogastral setae, and setiform posterior medial genital setae.

Records from Bermuda: BE 124: 1 adult. BE 310: 1 adult, 1 deutonymph.

General distribution: Antilles, Guadeloupe: under shrubs near the sea (Mahunka 1985a); Ecuador, Galapagos Islands: under Sesuvium shrubs in the littoral zone on Santa Cruz Island, in leaf litter of a dense elfin-forest on Volcán Alcedo (Isabela Island), in fern litter and moss near a fumarole on Fernandina Island (Schatz 1993); Central America: Belize Light House Reef: Half Moon Cay, in leaf litter (Schatz 1994b: 276; Schatz 2006); Cuba Ciudad de La Habana, Santiago de las Vegas, sugar cane (Saccharum spp.), leaf litter and soil (Prieto and Calderón 1992); first record for Bermuda.

\section{Lohmannia similis Balogh, 1962}

Balogh 1962: 59, f. 2; Balogh and Balogh 1987: 333, pl. 4 C; 1988: 54, pl. 33 G; 2002a: 64; 2002b: pl. 116:2; Schatz 1993: 80, figs. 25-30.

Dimensions: adult $(\mathrm{n}=17) 756(680-860) \times 354$ (325 - 380), larva $(n=7) 357(330-380) \times 192(170-$ $210)$, protonymph $(\mathrm{n}=4) 456(425-470) \times 226(210-$ 240), deutonymph $(\mathrm{n}=11) 533(510-570) \times 263(230$ - 280), tritonymph $(n=3) 697(630-740) \times 350(340-$ 360) $\mu \mathrm{m}$.

Sensillus with 10 branches in adult and tritonymph, 8-10 branches in deutonymph, 6-8 branches in larva and protonymph. Measurement of setae: adult $42-60 \times 18-25$, tritonymph $40 \times 21$ -22 , deutonymph $30-40 \times 15-20$, protonymph 27 - 30 x 14 - 16, larva $10-22$ x $5 \mu \mathrm{m}$. All notogastral setae slightly phylliform with serrated margins, measurements: c1 55 - 65, d1 $55-60$, e1 $60-67$, 
f1 $65-75 \mu \mathrm{m}$. Setae of ventral region as in population from the Galapagos Islands (Schatz 1993). Variation: Some adults bear 9 genital setae on one side.

Remarks: A direct comparison with specimens from Galapagos was possible. The specimens from Bermuda correspond to those and the description given in Schatz (1993) in most respects and are considered conspecific. Differences are the smaller body size in most of the population from Bermuda (Peru $830 \mu \mathrm{m}$, Galapagos 800-930 $\mu \mathrm{m}$ ), and slightly shorter notogastral setae. The two specimens from sample BE 301 have a larger body length of 830-860 $\mu \mathrm{m}$. Differences between Lohmannia similis Balogh, 1962 and the similar species L. lanceolata Grandjean, 1950 resp. L. bifoliata Willmann, 1936 are given in Schatz (1993).

Records from Bermuda: BE 59: 12 adults, 1 tritonymph, 11 deutonymphs, 3 protonymphs, 7 larvae. BE 230: 3 adults. BE 301: 2 adults, 2 tritonymphs, 1 protonymph.

General distribution: Peru: low rain forest plain in the Amazon valley near Iquitos, litter from dense forest and secondary forest (Balogh 1962); Ecuador, Galapagos Islands: numerously in the littoral zone, among algae and mangrove litter, also in litter of Miconia near Santa Rosa on Santa Cruz Island (Schatz 1993); first record for Bermuda.

\section{Meristacarus porcula Grandjean, 1934}

Grandjean 1934: 35, f. 7-10; Balogh and Balogh 1987: 340, pl. 22D; 1988: 56, pl. 37C; 2002a: 69; 2002b: pl. 122:9; Schatz 1994b: 278.

Dimensions: adult $(\mathrm{n}=1) 930 \times 580 \mu \mathrm{m}$.

Surface finely punctate. Sensillus with 16-18 short branches. Transverse bands on notogaster hardly visible, but corresponding to the speciesspecific pattern (Grandjean 1934). Notogastral setae long, c1 $205 \mu \mathrm{m}$, not reaching the lateral margin of notogaster, c3, ps1 $240 \mu \mathrm{m}$.

Remarks: The single specimen found in Bermuda corresponds to the original description (Grandjean 1934) and to the specimens found in Galapagos and Central America (Schatz 1994b) in most respects and are considered conspecific. The body size of the Bermuda specimen is slightly smaller than the population from the Galapagos Islands (length $1020-1070 \mu \mathrm{m}$ ) and from Cocos Island $(990-1065 \mu \mathrm{m})$. Grandjean (1934) reports a length of $950-1030 \mu \mathrm{m}$; Balogh and Balogh (1987) of $940-1090 \mu \mathrm{m}$.

Record from Bermuda: BE 310: 1 adult.

General distribution: Numerous reports from Central and South America: Panama, Guatemala, Martinique, Costa Rica: Cocos Island, Ecuador: Galapagos Islands (Schatz 1994b), Eastern Peru (Grandjean 1934, Balogh 1962); Africa: Ghana (Wallwork 1962); Philippines (Corpuz-Raros 1979). A widely distributed cirumtropical species, primarily litter inhabiting, in grasslands, plantations and secondary forests (Corpuz-Raros 1979), also in the littoral zone (Schatz 1994b); first record for Bermuda.

\section{Nesiacarus granulatus Hammer, 1972}

Hammer 1972: 14, f. 13; Balogh and Balogh 1987: 339, pl. 18 C-D; 1988: 339, pl. 19 A; 2002a: 68; 2002b: pl. 120:6; Schatz 1994b: 279.

Dimensions: adult $(\mathrm{n}=8) 501(480-525) \times 229$ $(220-230) \mu \mathrm{m}$.

Surface densely granulate. Anterior border of rostrum with a very slight incurvation. Sensillus with 10-12 branches. Notogaster with 21 pairs of notogastral setae, neotrichal setae $f^{\prime}$ distally to $f 1$ short, about same length as $f 1$, other neotrichal setae in posteromarginal position long. All prodorsal and notogastral setae ciliate. Measurements of setae: $c 115-22, c 215-25, c 365-70, d 115-22, d 225$ $-45, d 375, e 115-25, f 130-35, f^{\prime} 30-35, h 145-50$, posterior marginal setae $50-80 \mu \mathrm{m}$. Epimeral setae short and ciliate.

Juvenile instars: Larva and tritonymph encountered correspond to the adults in their speciesspecific characters. Dimensions: larva $(n=2) 260-$ $270 \times 125-130$, tritonymph $(\mathrm{n}=1) 430 \times 220 \mu \mathrm{m}$. Colour light yellow. Surface densely granulate. Sensillus with 10 branches in larva, 12 branches in tritonymph. Cuticle of sejugal articulation wide and striated in both instars. Larva with 13 pairs of notogastral setae, anterior median setae short (10 - 
$20 \mu \mathrm{m})$ and smooth, marginal and posterior setae long $(30-50 \mu \mathrm{m})$ and ciliate; tritonymph with 21 pairs of notogastral setae as in adult. Transverse bands well developed in both instars. Ventral region: Subcapitulum with 3 pairs of setae in larva, 4 pairs in tritonymph. Epimeral setal formula 3-12 in larva, 3-1-3-4 in tritonymph. Larva with Claparede organ between coxae I and II. Larval pseudanal plate with 3 pairs of short and smooth setae, tritonymph with 8 pairs of genital setae, 2 pairs of anal and 4 pairs of adanal setae, genital and anal setae as in adult.

Remarks: The specimens found in Bermuda correspond to the original description (Hammer 1972) and to the specimens found in Central America (Schatz 1994b) in most respects and are considered conspecific. The body size of the population from Bermuda is slightly smaller, but in the range of the populations from Tahiti and Central America.

Records from Bermuda: BE 26: 1 adult, 1 tritonymph. BE 117: 1 adult. BE 119: 4 adults, 2 larvae. BE 299: 2 adults.

General distribution: Tahiti, along the coast in Cyperus vegetation beneath a hedge (Hammer 1972); Japan, leaf litter from an evergreen broadleaved forest on a seaside hill near the southern end of Kasado-jima Island (Wada 1987), Ryukyu Islands (Aoki 2009); Central America: Belize and Guatemala: in moist, decayed leaf litter under dense tree and bush vegetation as well as in hardwood tropical rain forest (Schatz 1994b, 2006); first record for Bermuda.

\section{Papillacarus incompletus (Mahunka, 1985)}

Vepracarus incompletus: Mahunka 1985b: 126, figs. 611; Balogh and Balogh 1987; 336, pl. 13 A; 1988, 54: pl. 34 A-D; 2002a: 66; 2002b: pl. 118:5.

Dimensions: adult $(\mathrm{n}=2) 365-370 \times 160 \mu \mathrm{m}$. Colour light brown.

The specimens found in Bermuda were identified by comparison with the type specimens of this species. The populations of this species from St. Lucia, Antilles, and Bermuda are conspecific. The suture between the anal and adanal plates is undoubtedly complete, but weakly developed in the posterior part.
Papillacarus incompletus is similar to P. hirsutus (Aoki, 1961), which also has a spiculate secretion, setae with long cilia and strong neotrichy on the posterior part of the notogaster. The main differences between species are in the number of branches on sensilli (P. incompletus: $15-20$, P. hirsutus: $13-14)$, the length of the notogastral setae, (P. incompletus: notogastral setae of different lengths, posterior marginal setae longer, P. hirsutus: all notogastral setae short), the epimeral setal formula (P. incompletus: 9-4-3-4, P. hirsutus: 7-4-3-4), and length of adanal setae (P. incompletus: long, $P$. hirsutus: short).

A synonymy of Vepracarus with Papillacarus is supposed by Lee (1985) which is accepted by Colloff and Halliday (1998) and Subías (2004). Balogh and Balogh (1987) separate the two taxa by number and shape of the posterior notogastral setae: Papillacarus species have less (8-17) neotrichal setae, setiform and ciliate, Vepracarus species bear more (2050) neotrichal setae on the pygidium, with penicillate or arboriform shape.

Record from Bermuda: BE 184: 2 adults.

General distribution: St. Lucia, Lesser Antilles, at Castries, Vigie Point, in litter of a rocky forest, and in litter accumulated in rock crevices (Mahunka 1985b); Mexico, Quintana Roo: Sian Ka'an, lowland inundation forest, in leaf litter, moss and epiphytes (Vazquez 1999); Cuba, Prov. Habana, Nina Boñita, in soils of livestock farming (Palacios-Vargas and Socarras 1993, Socarras and Palacios-Vargas 1999); first record for Bermuda.

\section{Papillacarus spinosus Bischoff de Alzuet, 1972}

Bischoff de Alzuet 1972: 188, figs. 1-9; Balogh and Balogh 1987: 335, pl. 10 D; 1988: 54, pl. 34. Pillacarus spinosus (lapsus linguae): Balogh and Balogh 2002a: 65; 2002b: pl. 117:7-8.

Dimensions: adult $(\mathrm{n}=3) 535(525-550) \times 255$ (250-260), deutonymph (n=2) 370-390 x 180-195 $\mu \mathrm{m}$.

Colour light to medium brown in adult, yellowish white in deutonymph. Cuticula with a barely visible polygonale pattern, covered with small spines in both instars. Sensillus with 1416 branches in adult, 14 branches in deutonymph. 
Transverse bands hardly visible but present. Posterior concavity on notogaster weakly developed. Notogastral setae ciliate, measurements: $c 125-28$, c2 35-40, c3 68- $72 \mu \mathrm{m}$ in adult, c1 20, c2 20, c3 36 $\mu \mathrm{m}$ in deutonymph. Eight pairs of neotrichal setae in adult and deutonymph. Posterior marginal setae of deutonymph curved with comparatively long cilia. Subcapitulum with 6 pairs of setae in adult, 5 pairs in deutonymph. Epimeral setal formula 8-4-34 in adult, 5-2-3-3 in deutonymph. Row $a$ and the lateral setae of epimere I smooth, others ciliate.

Remarks: The specimens found in Bermuda correspond to the original description (Bischoff de Alzuet 1972) in most respects and are considered conspecific. A difference is the smaller body size of the adult specimens in Bermuda $(614 \times 305 \mu \mathrm{m}$ in the specimen from Argentina).

Records from Bermuda: BE 26: 2 adults, 1 deutonymph. BE 119: 1 adult, 1 deutonymph.

General distribution: Argentina, Entre Rios (Bischoff de Alzuet 1972), ecological conditions not mentioned; Mexico, Quintana Roo: Sian Ka'an, lowland inundation forest, in leaf litter and soil (Vazquez 1999); first record for Bermuda.

\section{Torpacarus omittens omittens Grandjean, 1950}

Torpacarus omittens Grandjean 1950: 126, f. 4-5; Balogh 1961: 30, f. 37-38; Wallwork 1962: 486; Bischoff de Alzuet 1971: 101. T. omittens omittens: Balogh and Mahunka 1981: 56; Balogh and Balogh 1987: 343, pl. 26 C-D; 1988: 58, pl. 39 A-B; 2002a: 71; 2002b: pl. 124: 10-11; Schatz 1994a: 171.

Dimensions (values for each specimen given in table 1): adult $(\mathrm{n}=7) 601(560-660) \times 278(255$ - 310), deutonymph $(\mathrm{n}=2) 420-425 \times 200-205$, tritonymph $(\mathrm{n}=3) 515(490-550) \times 253(230-280)$ $\mu \mathrm{m}$.

Sensillus with 10-14 branches in adult, 10 branches in deuto- and tritonymph. Transverse lines $m t, n t, p t$ on notogaster in most specimens present although very weakly developed, but in some specimens absent. Measurements of notogastral setae in adult: $c 1, d 1, e 110-17 \mu \mathrm{m}, c 244-90$ $\mu \mathrm{m}, d 270-80 \mu \mathrm{m}, f 1$ thickened, $65-100 \mu \mathrm{m}$, lateral and posteromarginal setae $90-120 \mu \mathrm{m}$. Setae $c 1$ and $d 1$ smooth, $p 1$ bilaterally ciliate, other dorsal setae unilaterally ciliate. Length ratio of notogastral setae in deuto- and tritonymph as in adult. Juvenile instars with some transverse rows of foveolae on notogaster. Inner epimeral setae smooth, shorter than the outer rows. Solenidion $\omega_{1}$ on tarsus I with a distinct dilation distally and frequently with one weaker dilation basally.

Remarks: The specimens found on Bermuda correspond to the original description (Grandjean 1950) in most respects and are considered conspecific. Balogh and Mahunka (1981) have described a subspecies from Paraguay, T. omittens paraguayensis (length 570-595 $\mu \mathrm{m}$ ), Schatz (1994a) described another subspecies from the Galapagos Islands, $T$. omittens galapagensis (length 620-660 $\mu \mathrm{m}$ ). The separation of both subspecies is based on different combinations of morphological characters (see Schatz 1994a). Some characters show a wide variability among the population on Bermuda (table 1):

1. Body size: Most specimens in Bermuda differ from the original description in having smaller body size $(560-580 \mu \mathrm{m})$ which correspond with a specimen from Ghana, West Africa (570 $\mu \mathrm{m}$, Wallwork 1962). Grandjean (1950) gives a body length of $600-650 \mu \mathrm{m}$ for the type population from Venezuela. Schatz (1994a) recorded a single individual from an island off the Belizean coast with a length of $680 \mu \mathrm{m}$. The specimens of sample BE 308 are distinctly larger (length of adult $650-660$ $\mu \mathrm{m}$, tritonymph $550 \mu \mathrm{m})$ than the rest of the Bermudan population, and the adults correspond in that respect with the type population.

2. Sensillus: The number of branches on sensillus is variable: 9 in specimens from Venezuela, 10-14 in specimens from Bermuda; 15-16 in other described subspecies.

3. Transverse lines on notogaster: Among the described subspecies this character is present only in T. omittens omittens. In most specimens from Bermuda the transverse lines are present but very weakly developed; in some specimens the lines are invisible. 
Schatz H. and Schuster R.

TABLE 1: Morphological features of Torpacarus omittens specimens from the Bermuda Islands. Measurements in $\mu \mathrm{m}$.

\begin{tabular}{|c|c|c|c|c|c|c|}
\hline Sample number & BE 184 & BE 184 & BE 184 & BE 184 & BE 225 & BE 225 \\
\hline Instar & Adult & Tritonymph & Deutonymph & Deutonymph & Adult & Adult \\
\hline Body size & $580 \times 265$ & $505 \times 230$ & $425 \times 205$ & $420 \times 200$ & $580 \times 275$ & $580 \times 265$ \\
\hline $\begin{array}{l}\text { Sensillus } \\
\text { branches }\end{array}$ & $10-12$ & 10 & 10 & 10 & 12 & 14 \\
\hline Transverse lines & present & $\begin{array}{l}\text { present, very } \\
\text { weak }\end{array}$ & $\begin{array}{l}\text { present, very } \\
\text { weak }\end{array}$ & present & absent & present \\
\hline Length c1/d1/e1 & $14 / 12 / 14$ & $14 / 12 / 12$ & $9-12 / 10 / 9$ & $11 / 11 / 11$ & $15 / 14 / 11$ & $13 / 12 / 10$ \\
\hline Length c2 / c3 & $50 / 110$ & $40 / 70$ & $30 / 61$ & $25 / 55$ & $50-55 / 90$ & $55 / 95$ \\
\hline Size ratio c2/c3 & $1 / 2$ & $<1 / 2$ & $1 / 2$ & $1 / 2$ & $1 / 2$ & $1 / 2$ \\
\hline Length f1 & 65 & 65 & 50 & 45 & 75 & 75 \\
\hline $\begin{array}{l}\text { Inner epimeral } \\
\text { setae } 1 \mathrm{a}-4 \mathrm{a}\end{array}$ & long, smooth & long, smooth & long, smooth & long, smooth & long, smooth & long, smooth \\
\hline $\begin{array}{l}\text { Dilations on } \\
\text { solenidion } w_{1} \\
\text { Tarsus I }\end{array}$ & $\begin{array}{l}1 \text { distinct } \\
\text { dilation }\end{array}$ & $\begin{array}{l}1 \text { distinct, } \\
1 \text { very weak } \\
\text { dilation }\end{array}$ & $\begin{array}{l}1 \text { distinct } \\
\text { dilation }\end{array}$ & $\begin{array}{l}1 \text { distinct, } \\
1 \text { very weak } \\
\text { dilation }\end{array}$ & $\begin{array}{l}1 \text { distinct } \\
\text { dilation }\end{array}$ & $\begin{array}{l}1 \text { distinct } \\
\text { dilation }\end{array}$ \\
\hline
\end{tabular}

\begin{tabular}{|c|c|c|c|c|c|c|}
\hline Sample number & BE 225 & BE 288 & BE 288 & BE 308 & BE 308 & BE 308 \\
\hline Instar & Tritonymph & Adult & Adult & Adult & Adult & Tritonymph \\
\hline Body size & $490 \times 250$ & $600 \times 290$ & $560 \times 255$ & $660 \times 285$ & $650 \times 310$ & $550 \times 280$ \\
\hline $\begin{array}{l}\text { Sensillus } \\
\text { branches }\end{array}$ & 10 & 12 & $10-12$ & 12 & 12 & 10 \\
\hline Transverse lines & present, weak & present & absent & $\begin{array}{l}\text { present, very } \\
\text { weak }\end{array}$ & $\begin{array}{l}\text { present, very } \\
\text { weak }\end{array}$ & $\begin{array}{l}\text { present, very } \\
\text { weak }\end{array}$ \\
\hline Length $\mathrm{c} 1 / \mathrm{d} 1 / \mathrm{e} 1$ & $15 / 13 / 13$ & $15 / 15 / 12$ & $14 / 15 / 12$ & $12 / 12 / 15$ & $16 / 16 / 17$ & $17 / 13 / 15$ \\
\hline Length c2 / c3 & $44 / 75-83$ & $45-65 / 85$ & $45 / 87$ & $90 / 110$ & $85 / 95$ & $80-90 / 100$ \\
\hline Ratio c2/c3 & $1 / 2$ & $<1 / 2$ & $1 / 2$ & almost $1 / 1$ & almost $1 / 1$ & almost $1 / 1$ \\
\hline Length f1 & 75 & 75 & 77 & 95 & 100 & 90 \\
\hline $\begin{array}{l}\text { Inner epimeral } \\
\text { setae } 1 \mathrm{a}-4 \mathrm{a}\end{array}$ & long, smooth & long, smooth & $\begin{array}{l}\text { long, } \\
\text { 1a ciliate, } \\
\text { 2-4 smooth }\end{array}$ & long, smooth & long, smooth & long, smooth \\
\hline $\begin{array}{l}\text { Dilations on } \\
\text { solenidion } w_{1} \\
\text { Tarsus I }\end{array}$ & $\begin{array}{l}1 \text { distinct } \\
\text { dilation }\end{array}$ & $\begin{array}{l}1 \text { distinct, } \\
1 \text { weak } \\
\text { dilation }\end{array}$ & $\begin{array}{l}1 \text { distinct } \\
\text { dilation }\end{array}$ & $\begin{array}{l}1 \text { weak } \\
\text { dilation }\end{array}$ & $\begin{array}{l}1 \text { very weak } \\
\text { dilation }\end{array}$ & $\begin{array}{l}1 \text { weak, } \\
1 \text { very weak } \\
\text { dilation }\end{array}$ \\
\hline
\end{tabular}


4. Length of notogastral setae: The size ratio of c2 : c3 is about $1: 2$ in most Bermudan specimens, as is usual in T. omittens omittens, but in specimens of sample BE 308 the setae $c 2$ are very long, causing a ratio of almost $1: 1$ (in adult and tritonymph). In the other described subspecies the setae $c 2$ are maximally half as long as setae $c 3$. The setae $f 1$ are long in all Bermudan specimens as is usual in T. omittens omittens and T. omittens paraguayensis.

5. Shape of inner epimeral setae: The epimeral setae of the median row $(1 a, 2 a, 3 a, 4 a)$ are long and smooth in most Bermudan specimens as is usual in T. omittens omittens, but in one adult of sample BE 288 setae $1 a$ are long and ciliate. In the other described subspecies these epimeral setae are long and ciliate in T. omittens paraguayensis resp. short and smooth in $T$. omittens galapagensis.

6. The solenidion $\omega 1$ on tarsus I has a distinct dilation distally in all populations of T. omittens omittens investigated in this respect, but one additional weaker basal dilation in most specimens in the population on Bermuda. The other described subspecies have 2 weaker dilations each.

These differences do not justify the separation of the population or part of the population of $T$. omittens omittens on Bermuda as a separate taxon. However, the variability of characters in different populations of this widespread species might be explained by isolation and the parthenogenetic reproduction mode of the Lohmanniidae (Norton and Palmer 1991).

Records from Bermuda: BE 184: 1 adult, 1 tritonymph, 2 deutonymphs. BE 225: 2 adults, 1 tritonymph. BE 288: 2 adults. BE 308: 2 adults, 1 tritonymph.

General distribution: In several places around the Caribbean Sea (Mexico, Belize, Panama, Cuba, Guadeloupe, St. Lucia, Venezuela) as well as in West Africa (detailed records listed in Grandjean 1950, Wallwork 1962, Mahunka 1985a, 1985b, Schatz 1994a, 2006, Starý 1998, Prieto and Schatz
2004, Subías et al. 2004); first record for Bermuda. Balogh (1962) and Bischoff de Alzuet (1971) recorded T. omittens also from Peru and Argentine. It is uncertain whether these individuals belong to T. omittens paraguayensis Balogh et Mahunka, 1981 or to T. omittens omittens Grandjean, 1950 (Schatz 1994a).

\section{ECOLOGICAL NOTES}

The Bermuda Islands are predominantly low without much ecological diversity. Most Lohmanniidae species occur in different rather terrestrial habitats, in sandy soils and leaf litter (Lohmannia jornoti, Meristacarus porcula, Nesiacarus granulatus, Papillacarus incompletus, P. spinosus, Torpacarus omittens omittens). Lohmannia banksi was the most frequent species on the islands (11 samples, 15 adults and 31 juvenile instars) in a wide range of habitats, from terrestrial locations in the interior with leaf litter and sandy soils to the edges of brackish and salty pools and the salt-drenched supralittoral zone. Haplacarus foliatus (2 samples, 5 juvenile instars) and Lohmannia similis ( 3 samples, 17 adults and 25 juvenile instars) were mainly found in sandy or muddy samples from the supralittoral zone.

Some Lohmannidae species (adults and juveniles) colonize the salt-spray area of the supralittoral zone and were even found in lower regions of the littoral zone, mainly in leaf litter near Avicennia mangroves (Haplacarus foliatus, Lohmannia similis). On the Galapagos Islands a total of 13 Lohmanniidae species was found (Schatz 1998, Schatz unpublished data), among them six species prevailing in the littoral zone, mainly in leaf litter under mangroves (including Lohmannia similis and Meristacarus porcula). Some of those species were even collected from the sea surface between the islands, washed from the shore (Peck 1994). But despite those findings in the border area between land and sea Lohmanniidae cannnot be considered to be exclusively thalassobiotic. Several members of the family seem to have a certain tolerance towards saline conditions, but as yet no species was found spending its whole life cycle in periodically inundated littoral zones. Furthermore Lohmanniidae 
species seem to avoid the littoral zone of rocky coasts. It is possible that their occurrence in saline conditions within the littoral zone is linked to the leaf litter of mangroves (Schuster, unpublished data of studies in Central and South America).

\section{ZOOGEOGRAPHICAL REMARKS}

Previous to this study no single Lohmanniid species was recorded from the Bermuda Islands. All species except Haplacarus foliatus were previously known from North, Central or South America: (North America, North Carolina: Lohmannia banksi. Central America: L. banksi, L. jornoti, Meristacarus porcula, Nesiacarus granulatus, Papillacarus incompletus, P. spinosus, Torpacarus omittens omittens. South America: Lohmannia similis, Meristacarus porcula, Papillacarus spinosus). Since the Bermuda Islands are situated in the Gulf Stream a hydrochorous dispersal from Central America can be assumed for most species, but also a zoochorous (by migrating birds and their nesting material) and anthropochorous dispersal with plant material seems possible.

\section{ACKNOWLEDGEMENTS}

The kind loan of type material by Dr. Sandor Mahunka, Budapest, Hungary (Papillacarus incompletus) and Dr. Roy A. Norton, Syracuse, New York (Lohmannia banksi) is gratefully acknowledged, also the assistance of Dr. Ohkubo, Japan in searching and translation of Japanese literature. The research program in Bermuda (RS) was supported by the Austrian Science Fund (FWF), project no. 3364. Thanks also to Wolfgang Sterrer, Bermuda, the former director of the BBSR, and his staff.

\section{REFERENCES}

Aoki J. 2009 — Oribatid mites of the Ryukyu Islands Tokai Press, Japan. pp. 223.

Balogh J. 1961 - An outline of the family Lohmanniidae Berl. 1916 (Acari: Oribatei) - Acta Zoologica Hungarica, $7: 19-44$

Balogh J. 1962 - Some new Lohmanniids from Peru (Acari: Oribatei) - Opuscula Zoologica (Budapest), 4: 59-61.
Balogh J., Balogh P. 1987 - A new outline of the family Lohmanniidae Berlese, 1916 (Acari, Oribatei) Acta Zoologica Academiae Scientiarum Hungaricae, 33: 327-398.

Balogh J., Balogh P. 1988 - Oribatid Mites of the Neotropical Region I - In: Balogh J. (Ed). The soil mites of the world. Budapest: Akademiai Kiadó, vol. 2. pp. 335.

Balogh J., Balogh P. 1990 - Oribatid Mites of the Neotropical Region II - In: Balogh J. (Ed). The soil mites of the world. Amsterdam: Elsevier, vol. 3. pp 333.

Balogh J., Balogh P. 2002a - Identification Keys to the Oribatid Mites of the Extra-Holarctic Regions - WellPress Publishing Limited, Miskolc, vol. I. pp. 453.

Balogh J., Balogh P. 2002b - Identification Keys to the Oribatid Mites of the Extra-Holarctic Regions - WellPress Publishing Limited, Miskolc, vol. II (plates). pp. 504.

Balogh J., Mahunka S. 1981 - New data to the knowledge of the oribatid fauna of the Neogea, VI. (Acari) - Acta Zoologica Academiae Scientiarum Hungaricae, 27: 49102.

Bischoff de Alzuet A. 1971 - Estudio comparativo de la region genito-anal en los distintos estados de Torpacarus omittens Grandjean (Acari: Lohmanniidae) Revista de la Sociedad Entomologica Argentina, 33: 101-104.

Bischoff de Alzuet A. 1972 - Sobre la presencia de Lohmanniidae en la Argentina (Acari, Cryptostigmata) - Physis, Buenos Aires, 31: 185-191.

Colloff M.J., Halliday R.B. 1998 - Oribatid Mites: A Catalogue of the Australian Genera and Species - Monographs on Invertebrate Taxonomy. CSIRO Publishing, Melbourne, vol. 6. pp 224.

Corpuz-Raros L.A. 1979 - Philippine Oribatei (Acarina) II. Family Lohmanniidae - Kalikasan, Philippine Journal of Biology, 8: 315-334.

Grandjean F. 1934 - La notation des poils gastronotiques et des poils dorsaux du propodosoma chez les Oribates (Acariens) - Bulletin de la Société zoologique de France, 59: 12-44.

Grandjean F. 1950 - Étude sur les Lohmanniidae (Oribates, Acariens) - Archives de Zoologie Experimentale et Generale, 87: 95-161.

Hammer M. 1972 - Tahiti. Investigation on the Oribatid fauna of Tahiti, and on some Oribatids found on the Atoll Rangiroa - Kongelige Danske Videnskabernes Selskab Biologiske Skrifter, 19(3). pp. 93.

Krisper G., Schuster R. 2008 - Fortuynia atlantica sp. nov., a thalassobiontic oribatid mite from the rocky coast of the Bermuda Islands (Acari: Oribatida: Fortuyniidae) - Annales Zoologici, Warszawa, 58: 419-432. doi:10.3161/000345408X326753 
Lee D.C. 1985 - Sarcoptiformes (Acari) of South Australian soils. 4. Primitive oribate mites (Cryptostigmata) with an extensive, unfissured hysteronotal shield and aptychoid - Records of the South Australian Museum (Adelaide), 19(4): 39-67.

Mahunka S. 1985a - Neue und interessante Milben aus dem Genfer Museum LVII. Oribatida Americana 9: Antilles I (Acari) — Revue suisse de Zoologie, 92: 119144.

Mahunka S. 1985b - Mites (Acari) from St. Lucia (Antilles) 2. Oribatida - Acta Zoologica Academiae Scientiarum Hungaricae, 31: 119-178.

McDaniel B., Norton R.A., Bolen E.G. 1979 - Mites of the family Lohmanniidae (Acarina: Oribatei) from Texas - Proceedings of the Entomological Society of Washington, 81: 621-629.

Niedbala W. 2002 - Ptyctimous mites (Acari: Oribatida) from Bermuda Islands - Annales Zoologici, Warszawa, 52: 181-188.

Norton R.A., Metz L.J., Sharma G.D. 1978 - Some Lohmanniidae (Acarina: Oribatei) from North and South Carolina forest soils - Journal of the Georgia Entomological Society, 13: 15-24.

Norton R.A., Palmer S. 1991 - The distribution, mechanisms and evolutionary significance of parthenogenesis in oribatid mites - In: Schuster R., Murphy P.W. (Eds.). The Acari: Reproduction, Development and Life-History Strategies. Chapman and Hall, London. p. 107-136.

Palacios-Vargas J.G., Socarras A.A. 1993 - Nuevos registros de Acaros oribátidos (Acarida: Oribatei) de suelos pecuarios de Cuba - Boletín de la Sociedad Mexicana de Entomología, 13: 13-15.

Peck S.B. 1994 - Sea-surface (pleuston) transport of insects between islands in the Galapagos Archipelago, Ecuador - Annals of the Entomological Society of America, 87: 576-582.

Pfingstl T., Schuster R. 2012 - First record of the littoral genus Alismobates (Acari: Oribatida) from the Atlantic ocean, with a redefinition of the family Fortuyniidae based on adult and juvenile morphology - Zootaxa, 3301: 1- 33.

Prieto D., Calderón L. 1992 - Registros de nuevos taxa de ácaros oribátidos (Acari: Cryptostigmata) para Cuba — Revista Biologia, La Habana (Cuba), 6: 144-145.

Prieto Trueba D., Schatz H. 2004 - Adiciones al catálogo de ácaros oribátidos (Acari, Oribatida) de Cuba - Revista Ibérica de Aracnología, 10: 303-310.

Schatz H. 1993 - The genus Lohmannia (Acari: Oribatida: Lohmanniidae) in the Galapagos Islands - Acarologia, 34: 69-84.

Schatz H. 1994a - New records of the genus Torpacarus (Acari: Oribatida: Lohmanniidae) from the Galapagos Islands and Central America - Acarologia, 35: 167179.
Schatz H. 1994b - Lohmanniidae (Acari: Oribatida) from the Galapagos Islands, the Cocos Island, and Central America - Acarologia, 35: 267-287.

Schatz H. 1998 - Oribatid mites (Acari: Oribatida) from the Galápagos Islands - Faunistics, Ecology and Speciation - Experimental and Applied Acarology, 22: 373-409. doi:10.1023/A:1006097928124

Schatz H. 2006 - Catalogue of known oribatid mite species (Acari: Oribatida) from the Central American landbridge (First part) - Tropical Zoology, 19: 209288.

Sellnick M. 1952 - Phauloppia gracilis, sp. n. (Acarina, Oribatoidea) from the Bermuda Islands - Annals and Magazine of Natural History, 12(5): 205-208. doi:10.1080/00222935208654282

Socarras A.A., Palacios-Vargas J.G. 1999 - Catálogo de los Oribatei (Acarina) de Cuba - Poeyana, 470-475: 1-8.

Starý J. 1998 - Torpacarus species (Acari: Oribatida: Lohmanniidae) from Cuba - Acta Societatis Zoologicae Bohemicae, 62: 57-68.

Subías L.S. 2004 - Listado sistemático, sinonímico y biogeográfico de los Ácaros Oribátidos (Acarifomes, Oribatida) del mundo (1748-2002) - Graellsia, 60: 3-305. doi:10.3989/graellsia.2004.v60.iExtra.218

Subías L.S., Zaballos J.P., Banda E., Fontal-Cazalla F., Nieves-Aldrey J.L. 2004 - Ácaros oribátidos (Acari, Oribatei) del Parque Nacional de la isla de Coiba, Panamá — Revista de Biología Tropical, 52: 85-95.

Thomas M.L.H. 2004 - The Natural History of Bermuda - Bermuda Zoological Society, Bermuda. pp. 255.

Vazquez M.M. 1999 - Catálogo de los ácaros oribátidos edáphicos de Sian Ka'an, Quintana Roo, México Universidad de Quintana Roo, Chetumal, Mexico. pp. 126.

Wada M. 1987 - Nesiacarus granulatus (Acari: Oribatida), a newly recorded species of oribatid mite from Japan — Edaphologia, 37: 17-19.

Wallwork J.A. 1962 - Some Oribatei of Ghana. X. The family Lohmanniidae - Acarologia, 4: 457-487.

Woolley T.A. 1966 - A review of the family Oripodidae (Acarina: Oribatei) - Transactions of the American Microscopic Society, 85: 2-29. doi:10.2307/3224772

\section{COPYRIGHT}

$($ (c) EY-No-ND Schatz H. and Schuster R. Acarologia is under free license. This open-access article is distributed under the terms of the Creative Commons-BY-NC-ND which permits unrestricted non-commercial use, distribution, and reproduction in any medium, provided the original author and source are credited. 